Biblica

et

Anna Magdalena Rambiert-Kwaśniewska

Papieski Wydział Teologiczny we Wrocławiu anna.rambiert@gmail.com

ORCID: 0000-0002-9491-6786

DOI: http://dx.doi.org/10.12775/BPTh.2018.006
Patristica

Thoruniensia

11 (2018) 1: 131-136

ISSN (print) 1689-5150

ISSN (online) 2450-7059

\title{
Stewart Moore, Jewish Ethnic Identity and Relations in Hellenistic Egypt. With Walls of Iron?, Supplements to the Journal for the Study of Judaism 171, Brill: Leiden-Boston 2015, ss. 291
}

\section{$\mathrm{T}$} emat gminy żydowskiej w Aleksandrii, którą wielu historyków uznaje za prototyp getta, należy wciąż do żywotnych i wartych zgłębiania. Przecież to właśnie na potrzeby tej wspólnoty dokonano pierwszego przekładu Biblii Hebrajskiej na język grecki. Tym bardziej zasadne wydaje się pytanie o tożsamość etniczną żydów zamieszkujących jedno z najważniejszych (o ile nie najważniejsze) miast hellenistycznego świata. $Z$ tym większą radością należy przyjąć fakt, że zgłębienia tego zagadnienia podjął się specjalista $\mathrm{w}$ dziedzinie judaizmu czasów drugiej świątyni, dr Stewart Moore z Fairfield University, który przystępnie ukazuje, że kłopot z tożsamością żydowską nie dotyczy wyłącznie współczesności, ale ma swoje korzenie antyczne. Autor referuje założenia czterech badaczy: model „rozdźwięku” i konfrontacji z obcą kulturą Johna J. Collinsa; W.E.B. DuBois’a o podwójnej tożsamości żydów egipskich, z których pierwsza była judzka, druga grecka; trójwymiarowy model Johna M.G. Barclaya, rozpatrujący stopień asymilacji, akulturacji i akomodacji oraz pozytywną wizję Ericha S. Gruena, który podkreśla, że literatura żydowska nie uprawia apologii, ale wchodzi w dialog z kulturą hellenistyczną, a nawet próbuje przekonać świat o własnej wyższości nad tym, co greckie (s. 2-4). Moore swoje cele ujmuje w trzy ambitne pytania: 1) Czy można odróżniać zachowania religijne od kulturowych, a jeśli tak, jaki jest ich stosunek do kategorii etniczności?; 2) Jak kształtowały się relacje kilku grup etnicznych, gdy wykluczymy ich wzajemną asymilację?; 3) Czy Judejczycy postrzegali odmienne grupy etniczne za obce czy pokrewne, niebezpieczne, neutralne czy pozytywne? (s. 5). Pomijając nowość ujęcia Moore’a, warto podkreślić również, że podejmuje się on zbadania przestrzeni nader często pomijanej - nie tylko relacji Judejczyków z Grekami w hellenistycznym Egipcie, ale również stosunku jednych i drugich do rodowitych Egipcjan, o których w tym okresie nader często się zapomina. 
Trzeba również przyklasnąć autorowi, który zwraca uwagę na nadużywanie pojęcia asymilacji w kontekście żydów egipskich oraz spłycenie jego znaczenia, wynikające z niezrozumienia mechanizmów działania tego zjawiska. Zasługą Moore’a jest spostrzeżenie tego, co jest bolączką biblistów i biblistyki in genere, której - z racji ogromnej liczebności badań i wykorzystywanych metod umykają często niezwykle doniosłe odkrycia w ramach dziedzin, w pewnym zakresie traktowanych jako subdyscypliny. Przykładem takiego zaniedbania jest, zdaniem autora, nieznajomość wiekopomnego Wstępu Frederica Bartha do wydanego w 1969 roku tomu Ethnic Groups and Boundaries: The Social Organization of Culture Difference - będącego punktem wyjścia dla Moore’a (być może - choć wciąż ciekawego - nieco przecenianego z racji jego osobistych zainteresowań).

Swoją pracę Moore podzielił na pięć zasadniczych części, skoncentrowanych na etniczności najpierw żydów judzkich, a następnie rekonstrukcji etniczności żydów egipskich w oparciu o przekaz tekstów papirusowych, o dzieła etnografów egipskich, literaturę apokaliptyczną rodem z Egiptu oraz, na końcu, o słynny List Arysteasza do Filokratesa - źródło legendy o powstaniu Septuaginty. Pierwszy rozdział poświęca autor przeglądowi dostępnych w badaniu etniczności metodologii i koncepcji, ukazując ich plusy i minusy (s. 7-44). Bierze pod lupę funkcjonalizm (a właściwie Structural-Functionalism) w wydaniu Émile’a Durkheima (którego koncepcje uznaje ostatecznie za nieaplikowalne, ponieważ wymagają one codziennej obserwacji, co w studiach starożytniczych jest niemożliwe) i Talcotta Parsonsa (s. 8-13) a następnie omawia prymordializm Edwarda Shilsa (s. 13-15) i jego krytykę (ponieważ nie można mieszać koncepcji ludowych z rzeczywistością społeczną - s. 15), ukazując dalej, $\mathrm{w}$ jaki sposób teorie te, $\mathrm{z}$ dodaniem nacjonalizmu, przykładali do judaizmu tacy specjaliści od czasów drugiej świątyni jak: Bickerman, Hengel, Tcherikover, Feldman, Mendels, Goodblatt i in. (s. 15-20) oraz jak je na rzecz judaizmu/żydowskości rozszerzono (s. 20-25), uznając choćby żydów egipskich za pełnoprawnych Hellenów (Modrzejewski). Poświęca również miejsce ujęciom „poza-Durkheimowskim”, które ostatecznie uważa za obiecujące w kontekście pracy z tekstami antycznymi. W pierwszej kolejności przytacza poglądy szkoły chicagowskiej oraz G. Simmela, dalej bezpośrednich poprzedników Bartha: Kahinsa, Moermana oraz kilku uczonych, którzy zaprezentowali swoje poglądy na sympozjum w Norwegii. Owe odczyty zostały opublikowane i opatrzone Wstępem Federica Bartha, który ewidentnie jest dla całej pracy Moore’a kluczowy. Nowością u Bartha było, wedle Moore’a, dostrzeżenie trwałości granic etnicznych, pomimo przepływu ludności pomiędzy grupami. Warunkiem zachowania granic, jak twierdził Barth, nie było całkowite odseparowanie kultur, ale zgoda obu stron, by niektóre z etnicznych wyróżników (które, notabene, nie 
są wrodzone) te granice etniczne określały. Od trwałości tych wyróżników zależałoby zatem utrzymanie etnicznej odrębności. Nawet jeśli ulegają one zmianie, ale nie wszystkie na raz, granica zostaje zachowana. Nietrudno te poglądy przyłożyć do gminy aleksandryjskiej - nie dziwi więc, że koncepcja Bartha stała się silną inspiracją dla Moore’a. Poglądy Bartha, kontynuuje Moore, wpłynęły najmocniej na spadkobierców szkoły chicagowskiej, związanych z tzw. interakcjonizmem symbolicznym, którzy podkreślali, że osobista tożsamość formowana jest w procesie społecznych interakcji, które mogą zostać przez osobę wykorzystane przy osiąganiu pewnych celów (s. 37).

Wszystkie przytoczone przez Moore’a poglądy i ich krytyka umożliwiły mu wypracowanie własnej metodologii, która pozwalała rzucić miarodajne światło na tożsamość żydowską w oparciu o teksty powstałe w odległych czasach, w rekonstruowanym na ich podstawie kontekście kulturowym. Za to rzetelne opracowanie, ukazujące cały proces narodzin teorii Bartha i jego własnej metodologii, należy się Moore’owi uznanie, ponieważ otworzył przed biblistami drzwi do wciąż mało znanego świata antropologii kulturowej w pełnym jej splendorze.

Po dokładnym metodologicznym wprowadzeniu, autor przechodzi do meritum, pokazując jak aplikować metodę, którą on sam uznał za najbardziej adekwatną. Swoje badania opiera o szereg trafnie sformułowanych pytań (s. 45-96): które znaczniki kulturowe są ważne? Jak postrzegali je Judejczycy w określonych czasach i miejscach? Czy wszystkie wyróżniki były religijne, czy niektóre z nich świeckie? Co znamionuje osobę, którą uznaje się za Judejczyka/ Hellena/Egipcjanina? oraz najważniejsze - co odróżniało Judejczyków od ich sąsiadów? Wszelkie analizy - co niezwykle ważne - rozpoczyna od przeglądu często drugorzędnie traktowanych tekstów papirusowych, zbierając, porządkując i wydobywając te dane, które dla opisu tożsamości żydów egipskich są najważniejsze. Dochodzi do bardzo cennego wniosku o nieaktualności dwóch idei promowanych przez dawniejszych badaczy: Mischkultur i „dwóch samotności”. Przytaczając bardzo konkretne źródła, dowodzi, że skoro istniała przestrzeń kulturowych interakcji między Egipcjanami i Grekami, to podobne interakcje zachodziły między Egipcjanami a Judejczykami, przy jednoczesnym zachowaniu granic kulturowych, które były wyznaczane m.in. przez szabat i horkos patrios. Co ciekawe, Moore konkretyzuje definicję relacji żydowsko-egipskich mówiąc raczej o pograniczu (borderland) niż granicy (borderline), dostrzegając istnienie podwójnej tożsamości niektórych egipskich żydów, widocznej w nadawanych imionach. Moore dochodzi również do bardzo interesującego spostrzeżenia, że szabat praktykowany był przez ludzi o podwójnej, egipsko-żydowskiej tożsamości, czego dowodem jest przeniknięcie terminu šbtj do onomastykonu demotycznego. Co jednak zaskakuje, praktykowanie szabatu dla greckich etnografów okresu ptolemejskiego nie było aż tak jaskrawym wy- 
różnikiem kulturowym, skoro mieli oni problem z odróżnianiem Judejczyków od Egipcjan. Ważnym wyznacznikiem etnicznym okazuje się natomiast wykorzystanie LXX, odnotowane wśród żydów z Herakleopolis, a także rytuały ślubne i związane z rozwodem oraz horkos patrios. Nie były one jednak na tyle jednoznaczne, by stanowić wyraźną granicę etniczną zarówno między Egipcjanami i Judejczykami, jak i Grekami i Judejczykami - reasumuje Moore (s. 96).

W kolejnym rozdziale (ss. 97-151) Moore bierze pod uwagę literaturę grecką, konkretnie grecką historiografię w wydaniu m.in. Herodota i Strabona, hellenistyczną etnografię dotykającą spraw egipskich oraz tę, która rzuca światło na problem etniczności Judejczyków. Już na przykładzie Herodota ukazuje, że o granicach etnicznych decydowali m.in. kapłani po stronie egipskiej. Z charakterystyczną dla siebie wnikliwością omawia różnice etniczne (mumifikację, różnice żywieniowe oraz językowe), by dość dosadnie podkreślić odrębność Greków i Egipcjan. Inni etnografowie - obok Herodota - (np. Diodor) opisują wspomnianą granicę jako nieprzekraczalną. Tymczasem Hekatajos i Strabon uznają granicę między Grekami i Egipcjanami za nie dość wyraźną. Tę zmianę w postrzeganiu granic Moore słusznie tłumaczy znaczną zmianą etnicznego oddziaływania w czasach ptolemejskich. Co jednak interesujące, postrzeganie wcześniejszych relacji, choćby przez Herodota, nie znajduje swojego odzwierciedlenia w tekstach papirusowych, które ukazują Egipt jako mocno wewnętrznie podzielony - czym tłumaczy Moore nieistnienie takiego zjawiska, jak choćby egipski nacjonalizm. A co z żydami? Etnografowie uznają ich (m.in. za sprawą praktykowanego również przez rdzennych mieszkańców obrzezania) za grupę Egipcjan - pomimo restrykcyjnych przepisów żywieniowych oraz przestrzegania szabatu. Moore sądzi, że taki brak granic mógł być dla Judejczyków sygnałem do wyraźniejszego zaznaczenia własnych etnicznych granic, które zostały niebezpiecznie zatarte. Gdy zaś mowa o Grekach, autor znów zauważa godną uwagi rzecz. Wyróżnikiem etniczności Greków były głównie igrzyska i gimnazjon, wszystkożerność oraz gościnność, ale już nie język. Tak subtelne granice uczyniły z "greckości” doskonałego pogromcę odmiennych tożsamości.

Dalej, autor bierze pod uwagę egipską i żydowską apokaliptykę (s. 152203). Gdy mowa o pierwszej, koncentruje się ona głównie na przywódcy, który powinien być etnicznym Egipcjaninem. Rządy ptolemejskie są w tej wizji przejściowe, ale wizje w swojej wymowie nie są antygreckie. Niemniej, teksty te dowodzą, że doszło w społecznościach egipskich do znacznego zatarcia granic. Gdy mowa o Judejczykach - reakcje są podobne. Podupadający ekonomicznie Egipt Ptolemeuszy miał wpływ na pogorszenie relacji między grupami etnicznymi. A skoro doszło do pogorszenia, wcześniejsze relacje musiały być bliskie. Doskonałym tego wyrazem są Wyrocznie Sybilli, w których III księdze silnie 
podkreśla się monoteizm i zakaz obrazowania Boga jako silne wyróżniki etniczne, które nie były jednak eksponowane po to, by poróżnić sąsiadów. Moore zauważa słusznie, że popsucie relacji i wszelkie nasilające się w II w. przed Chr. konflikty etniczne były owocem zmian społeczno-ekonomicznych i politycznych, a nie ksenofobii.

Pod koniec swoich poszukiwań, Moore skupia się na najbardziej wymownym źródle - opowiadaniu o początkach LXX (s. 204-254). List Arysteasza ukazuje, że Judejczycy adaptowali hellenizm na własną modłę, zachowując przy tym własne wyznaczniki etniczności (s. 207), nawet jeśli niektórzy badacze, których stanowiska pieczołowicie przywołuje, z powodzeniem dowodzą wciąż, że żydzi w pełni zintegrowali się z sąsiadami a List pełnił jedynie funkcję mitu etiologicznego (Honigman, s. 209). Sam Moore, konfrontując się z różnymi stanowiskami, poprzez analizę różnych źródeł oraz, na ich podstawie, relacji grup etnicznych (głównie Egipcjan, Greków i Judejczyków), dochodzi jednak do wniosku, że nie ma dowodu na istnienie jakichkolwiek niepokojów wśród samych Żydów, które wypływałyby ze strachu przed utratą „judejskości” na rzecz kultury greckiej, a List jest co najwyżej sygnałem, że takowe mogłyby zaistnieć. Zauważył, że z jednej strony Żydzi zamieszkujący Egipt mocno podkreślali własną tożsamość, choćby przestrzegając szabatu, z drugiej - mieli wolną rękę w adaptowaniu pewnych elementów obcych kulturowo, ale wyłącznie tych, które nie stały w sprzeczności z ich własnymi cechami etnicznymi. Chodzi o praktyki tak niegroźne, jak choćby nadawanie greckich czy egipskich imion. I choć List Arysteasza do Filokratesa odmalowuje według Moore’a obraz wspólnoty silnie zhellenizowanej, to jednak mocno przywiązanej do własnych wyróżników etnicznych.

Moore przedarł się przez niezwykle bogaty materiał. Daje temu wyraz już w omówieniu ewoluującej teorii etniczności, jedną z nich przykładając ostatecznie do żydów aleksandryjskich. Autor decyduje się podążyć za wyważonym stanowiskiem Federica Bartha, które - jak wynika z wnikliwych analiz literatury źródłowej i dokumentów - doskonale sprawdziło się w badaniach nad etnicznością Judejczyków, jak zwykł pisać autor. Stosowany przez Moore’a w całej pracy termin Judejczyk zamiast żyd dowodzi konsekwencji badacza (przypis 1). Na uwagę zasługuje język autora, który o kwestiach niezwykle zawiłych pisze w sposób przystępny i precyzyjny. Z radością należy przyjąć tak wnikliwe studium o tożsamości i żywić nadzieję, że jego treść zostanie szerzej poznana nie tylko za sprawą pobieżnego streszczenia w przedkładanej recenzji. 


\section{Bibliografia}

Barclay J. M. G., Jews in the Mediterranean Diaspora: From Alexander to Trajan (323bce$-117 c e)$, Berkeley 1996.

The Cambridge History of Judaism 2: The Hellenistic Age, red. D. Davies, L. Finkelstein, Cambridge 1989.

Collins J. J., Between Athens and Jerusalem: Jewish Identity in the Hellenistic Diaspora, Grand Rapids 2000.

Collins J. J., Jewish Cult and Hellenistic Culture: Essays on the Jewish Encounter with Hellenism and Roman Rule, Leiden-Boston 2005.

Feldman L. H., Jew and Gentile in the Ancient World: Attitudes and Interactions from Alexander to Justinian, Princeton 1993.

Feldman L. H., Judaism and Hellenism Reconsidered, Leiden 2006.

Gruen E. S., Heritage and Hellenism. The Reinvention of Jewish Tradition, Berkeley 1998.

Gruen E. S., Diaspora. Jews amidst Greeks and Romans, Cambridge 2002.

Hengel M., Judaism and Hellenism. Studies in Their Encounter in Palestine During the Early Hellenistic Period, tłum. J. Bowden, Philadelphia 2004.

Horst P. W. van der, Jews and Christians in their Graeco-Roman Context. Selected Essays on early Judaism, Samaritanism, Hellenism, and Christianity, Tübingen 2006.

Kreuzer S., The Bible in Greek Translation, Transmission, and Theology of the Septuagint, Atlata 2015.

Stebnicka K., Tożsamość diaspory. Żydzi w Azji Mniejszej okresu Cesarstwa, Warszawa 2011.

Tcherikover V., Hellenistic civilization and the Jews, tłum. S. Applebaum, Grand Rapids 2011. 